\begin{tabular}{|l|l|l||}
\hline \multicolumn{2}{|c|}{ PublisherInfo } \\
\hline \hline PublisherName & $:$ & BioMed Central \\
\hline \hline PublisherLocation & $:$ & London \\
\hline \hline PublisherImprintName & $:$ & BioMed Central \\
\hline \hline
\end{tabular}

\title{
MHC class I upregulation and myositis
}

\begin{tabular}{|l|l|l||}
\hline \multicolumn{2}{|c|}{ ArticleInfo } \\
\hline \hline ArticleID & $:$ & 163 \\
\hline \hline ArticleDOI & $:$ & $10.1186 /$ ar-2000-66833 \\
\hline \hline ArticleCitationID & $:$ & 66833 \\
\hline \hline ArticleSequenceNumber & $:$ & 120 \\
\hline \hline ArticleCategory & $:$ & Paper Report \\
\hline ArticleFirstPage & $:$ & 1 \\
\hline \hline ArticleLastPage & $:$ & 3 \\
\hline \hline & & RegistrationDate : 2000-8-23 \\
\hline ArticleHistory & $:$ & OnlineDate \\
\hline \hline ArticleCopyright & $:$ & Current Science Ltd2000-8-23 \\
\hline \hline ArticleGrants & $:$ & \\
\hline \hline ArticleContext & $:$ & 130753311 \\
\hline \hline
\end{tabular}




\section{Keywords}

autoimmunity, MHC class I, myositis, transgenic mice

\section{Context}

In many human inflammatory myopathies (eg polymyositis and dermatomyositis) the widespread expression of MHC class I molecules on the surface of muscle cells preceeds the inflammatory condition. Although there is no consistent correlation, MHC class I molecules can be upregulated in response to pro-inflammatory cytokines, even though they are rarely expressed on skeletal muscle cells. In addition, the overexpression of MHC class I molecules in several different tissues can cause the destruction of the targeted tissue. To investigate whether the prolonged expression of MHC class I molecules on the surface of muscle cells could be sufficient to cause the development of myositis.

\section{Significant findings}

Overexpression of MHC class I molecules in utero is lethal; therefore, transgenic animals were maintained on doxycycline, a tetracycline analog, to suppress $\mathrm{H}-2 \mathrm{~Kb}$ expression until genotyping at 4 weeks of age. Offspring were phenotypically and histologically normal. Skeletal muscle $\mathrm{H}-2 \mathrm{~Kb}$ expression was then induced by removing the doxycycline; mice transgenic for both transgenes $(\mathrm{H}+/ \mathrm{T}+)$ developed clinical signs of muscle weakness 2 months after expression of transgenes began. These symptoms, more severe in females, were accompanied by increased levels of creatinine phosphokinase and glutamic-oxaloacetic transaminase, indicating ongoing muscle parenchymal damage. Histological and immunohistochemical studies revealed muscle fibre degeneration and inflammatory changes. No abnormalities were found in the heart, liver, kidney, lung, skin or spleen. In addition $\mathrm{H}-2 \mathrm{~Kb}$ expression resulted in detectable levels of antinuclear antibodies in 5 out of $18 \mathrm{H}+/ \mathrm{T}+$ mice, yielding a fine cytoplasmic immunofluorescent staining pattern. Elevated levels of antibodies to the myositis-specific targeted autoantigen HRS were detected by ELISA and the specificity of the ELISA-positive samples was confirmed by western blotting. No histological or clinical improvement was observed in $\mathrm{H}+/ \mathrm{T}+$ mice when doxycycline was given after the disease was clinically recognised. 


\section{Comments}

This interesting paper suggests that a non specific stimulus can give rise to a highly specific pattern of autoimmune disease. Conditional up-regulation of MHC class I gene in skeletal muscle resulted in a self-sustained autoimmune myositis in mice. The disease was accompanied by the development of autoantibodies including antibodies to histidyl-tRNA synthetase (HRS) as is characteristic of polymyositis in humans; however, the route leading from the expression of the transgene to the antiHRS antibodies is still a matter of speculation and the exact role of such antibodies in the pathogenesis remains to be established. It is interesting to note that this model supports other experimental systems where the specificity of the autoantibodies derives not from the specificity of the promoting stimulus, but from its context, location and duration.

\section{Methods}

Transgenic mice expressing MHC class I molecules $(\mathrm{H}-2 \mathrm{~Kb})$ under the control of a tetracyclineresponsive element $\left(\mathrm{H}^{+}\right)$were crossed with mice that express a tetracycline-controlled transactivator under the control of a muscle creatine kinase promoter $(\mathrm{T}+)$. The expression of both transgenes was identified by Southern blotting and confirmed by northern blot analysis of skeletal muscle mRNA. RNA protection assays with custom-made cytokine multiprobe template sets were used for quantifying the expression of pro-inflammatory cytokines and chemokines. Locomotor activity was tested in an open field Digiscan apparatus by recording, every 10 minutes, the total distance and the vertical activity. Serum creatinine phosphokinase and glutamic-oxaloacetic transaminase levels were measured by an automatic analyser. Antinuclear antibodies were detected by immunofluorescence with Hep2 cells and antibodies to HRS were quantitated by ELISA. Histological and immunohistochemical analyses were used to determine the morphological status of the muscle tissue.

\section{References}

1. Nagaraju K, Raben N, Loeffler L, Parker T, Rochon PJ, Lee E, Danning C, Wada R, Thompson C, Bahtiyar G, Craft J, van Huijsduijnen RH, Plotz P: Conditional up-regulation of MHC class I in skeletal muscle leads to self-sustaining autoimmune myositis. Proc Natl Acad Sci U S A. 2000, 97: 9209-9214.

This PDF file was created after publication. 